\title{
Sphincterotomy alone versus sphincterotomy and biliary stent placement in the treatment of bile leaks: 10 year experience at a quaternary hospital
}

\author{
Victor K FLUMIGNAN ${ }^{1}$, Amit H SACHDEV ${ }^{2}$, João P S NUNES ${ }^{1}$, Pamela F SILVA ${ }^{3}$, \\ Lucca H B PIRES ${ }^{3}$ and Mariana M ANDREOTI ${ }^{3}$
}

Received: 12 August 2020

Accepted: 29 September 2020

\begin{abstract}
Background - Hepatobiliary surgery and hepatic trauma are frequent causes of bile leaks and this feared complication can be safely managed by endoscopic retrograde cholangiopancreatography (ERCP). The approach consists of sphincterotomy alone, biliary stenting or a combination of the two but the optimal form remains unclear. Objective - The aim of this study is to compare sphincterotomy alone versus sphincterotomy plus biliary stent placement in the treatment of post-surgical and traumatic bile leaks. Methods - We retrospectively analyzed 31 patients with the final ERCP diagnosis of "bile leak". Data collected included patient demographics, etiology of the leak and the procedure details. The treatment techniques were divided into two groups: sphincterotomy alone vs. sphincterotomy plus biliary stenting. We evaluated the volume of the abdominal surgical drain before and after each procedure and the number of days needed until cessation of drainage post ERCP. Results - A total of 31 patients (18 men and 3 women; mean age, 51 years) with bile leaks were evaluated. Laparoscopic cholecystectomy was the etiology of the leak in 14 ( $45 \%$ ) cases, followed by conventional cholecystectomy in $9(29 \%)$ patients, hepatic trauma in $5(16 \%)$ patients, and hepatectomy secondary to neoplasia in $3(9.7 \%)$ patients. The most frequent location of the leaks was the cystic duct stump with $12(38.6 \%)$ cases, followed by hepatic common duct in $10(32 \%)$ cases, common bile duct in $7(22 \%)$ cases and the liver bed in $2(6.5 \%)$ cases. $71 \%$ of the patients were treated with sphincterotomy plus biliary stenting, and $29 \%$ with sphincterotomy alone. There was significant difference between the volume drained before and after both procedures $(P<0.05)$. However, when comparing sphincterotomy alone and sphincterotomy plus biliary stenting, regarding the volume drained and the days needed to cessation of drainage, there was no statistical difference in both cases $(P>0.005)$. Conclusion - ERCP remains the first line treatment for bile leaks with no difference between sphincterotomy alone vs sphincterotomy plus stent placement.
\end{abstract}

HEADINGS - Fístula biliar. Sphincterotomy. Stents. Endoscopic retrograde cholangiopancreatography. Cholecystectomy.

\section{INTRODUCTION}

Bile leaks are a potentially serious complication that can occur after cholecystectomy, liver transplantation, partial hepatectomy, and hepatic damage secondary to abdominal trauma ${ }^{(1,2)}$. Although post cholecystectomy surgery is responsible for most of biliary injuries, it occurs with an incidence of only $1 \%{ }^{(3,4)}$. In hepatic resections and liver transplantations the incidence of bile duct injury ranges from $2 \%$ to $25 \%{ }^{(3)}$. Regarding hepatic trauma, the non-operative management of hemodynamically stable patients has become the standard practice in most trauma centers achieving $85 \%$ success rate ${ }^{(5,6)}$.

Conventional cholecystectomy has been replaced with laparoscopic cholecystectomy in the treatment of gallstones over the past three decades ${ }^{(7,8)}$. The laparoscopic approach is safe, effective and allows early discharge from the hospital as well as a faster recovery and better cosmetic results ${ }^{(7,9,10)}$. Despite the advantages of the laparoscopic approach this procedure is also related with higher rates of iatrogenic biliary injury (about $1 \%$ of all laparoscopic $\mathrm{x}$
$0.2 \%$ of conventional cholecystectomy $)^{(7,9)}$. The principal causes of these injuries are the inadequate clipping of the cystic duct, misidentification of the anatomy, leaks from the gall bladder bed and thermal strictures ${ }^{(7)}$.

Despite the improvements in perioperative treatment, hepatobiliary surgery is still associated with a high level of morbidity, especially after liver resection with morbidity higher than $20 \%$ and bile leaks occurring in approximately $7 \%$ of these procedures ${ }^{(11)}$. Unlike post cholecystectomy bile leaks, hepatobiliary surgery associated bile leaks can occur in different locations such as the anastomosis, or in the cut surface of the liver ${ }^{(3)}$.

Bile leaks secondary to blunt or penetrating hepatic trauma are also a common and potentially a severe complication. The non-operative management of stable patients as well as the "damage control" techniques for unstable patients has been improving survival even in severe extensive hepatic parenchymal damage. As a result of the improved survival, bile leaks have become a frequent secondary complication ${ }^{(5)}$.

Endoscopic retrograde cholangiopancreatography (ERCP)

Declared conflict of interest of all authors: none

Disclosure of funding: no funding received

${ }^{1}$ Hospital Santa Marcelina, São Paulo, SP, Brasil. ${ }^{2}$ Walter Reed Medical Center, Washington D.C., USA. ${ }^{3}$ Faculdade Santa Marcelina, São Paulo, Brasil.

Corresponding author: Victor Kalil Flumignan. E-mail: victor_flumignan@hotmail.com 
is the standard method used to diagnose bile leaks (BL), with the capacity to determine the location of the leak in more than $95 \%$ of the cases ${ }^{(3,12,13)}$. An important advantage of ERCP is the possibility of diagnosing and treating the leak in the same procedure. The goal of the endoscopic treatment is to eliminate the transpapillary pressure by performing a sphincterotomy, placing a biliary stent or the combination of both, lowering the pressure on the bile duct which allows healing the leak ${ }^{(1,3)}$. Large and refractory bile leaks are often treated with multiple plastic stents or self-expandable metal stents (SEMS), and usually stents are removed after 4 to 8 weeks ${ }^{(2)}$.

The aims of this study are to determine efficacy of endoscopic treatment of bile leaks secondary to cholecystectomy, hepatectomies, and hepatic trauma and to compare the currently employed ERCP approaches to biliary leaks: endoscopic sphincterotomy alone and sphincterotomy plus biliary stenting, regarding the number of days needed to remove the abdominal surgical drain or cessation of drainage after each technique.

\section{METHODS}

This study was approved by the Ethics and Research Committee of Hospital Santa Marcelina, São Paulo. Hospital Santa Marcelina is a quaternary teaching hospital, trauma and cancer referral center, with a high number of surgeries performed per year. We retrospectively analyzed all ERCPs performed in the hospital between the years of 2009 and 2019. All procedures were performed by an advanced endoscopy fellow under the supervision of one experienced interventional endoscopist. Deep sedation, or general anesthesia were used according to the patient status. More than 1200 cases were analyzed and all patients who had a previous ERCP were excluded. From 1200 cases analyzed, we found 31 cases with a final diagnosis of "Bile Leak", and these were included in this study. Data collected included age, gender, etiology, and localization of the leak, primary catheterization, biliary dilatation, necessity of reoperation for suture the leak after the ERCP, and finally if the endoscopy treatment was therapeutic.

Etiology of the leaks were divided into four groups: conventional cholecystectomy, laparoscopic cholecystectomy, hepatectomy due to neoplasia and hepatic trauma. The locations of the leaks were divided in four major groups: cystic duct stump, common bile duct, hepatic common duct, and hepatic bed.

Our aim was to compare sphincterotomy alone with sphincterotomy plus stent placement. The decision to perform sphincterotomy alone or sphincterotomy plus stent placement was made by the endoscopist. In all stent cases, plastic stents were used measuring 8.5 or 10 Fr according to availability. Therapeutic success was determined when there was no need for further surgery or radiological interventions after the ERCP was performed.

Before initiating data analysis, we applied Shapiro-Wilk test to verify the normality of the data $(95 \% \mathrm{CI})$. After verification of normality we applied the non-parametric test.

Data was analyzed by using the IBM-SPSS software version 22 for Windows. All the tests were realized with statistical significance of $5 \%$ ( $P$ values $\leq 0.05)$. To compare the volume drained before and after each technique (Stent x Sphincterotomy), were applied Wilcoxon tests for selected variables and the U de Mann-Whitney test for independent variable, both with $95 \%$ CI. To analyze days until the drain has been solved after each treatment the U de MannWhitney were applied with $95 \%$ CI.

\section{RESULTS}

A total of 31 patients undergoing ERCP between 2009 and 2019 with the final diagnosis of "bile leak" were analyzed. Amongst the 31 patients, $18(58 \%)$ were men and $13(42 \%)$ were women. The mean age was 51.5 years (range $24-87$ ). The clinical variables are seen in TABLE 1. Laparoscopic cholecystectomy was the etiology of the leak in 14 of the $31(45 \%)$ cases, followed by conventional cholecystectomy with $9(29 \%)$ cases, hepatic trauma with $5(16 \%)$ cases and hepatectomy with $3(9.7 \%)$ cases. Primary catheterization of the papilla was possible in $24(77 \%)$, while in the remaining $7(22 \%)$ cases fistulotomy (infundibulotomy) was successfully performed.

TABLE 1 . Clinic variables.

\begin{tabular}{lcc}
\hline Variables & $\mathrm{n}$ & $\%$ \\
\hline Etiology of the leak & & \\
Conventional cholecystectomy & 9 & $29.0 \%$ \\
Laparoscopic cholecystectomy & 14 & $45.2 \%$ \\
Partial hepatectomy due to neoplasia & 3 & $9.7 \%$ \\
Hepatic trauma & 5 & $16.1 \%$ \\
Location of the leak & & \\
Cystic duct stump & 12 & $38.6 \%$ \\
Common bile duct & 7 & $22.6 \%$ \\
Common hepatic duct & 10 & $32.3 \%$ \\
Hepatic bed & 2 & $6.5 \%$ \\
Primary catheterization & & \\
No & 7 & $22.6 \%$ \\
Yes & 24 & $77.4 \%$ \\
Biliary dilatation & & \\
No & 23 & $74.2 \%$ \\
Yes & 8 & $25.8 \%$ \\
Reoperation for suture the leak & & \\
No & 30 & $96.8 \%$ \\
Yes & 2 & $6.5 \%$ \\
Endoscopy was therapeutic? & & \\
No & 2 & $6.5 \%$ \\
Yes & 29 & $93.5 \%$ \\
\hline
\end{tabular}

The most frequent location of the leaks were the cystic duct stump with $12(38.6 \%)$ cases, followed by hepatic common duct with $10(32 \%)$ cases, common bile duct with $7(22 \%)$ cases and the liver bed with $2(6.5 \%)$ cases. The post laparoscopic cholecystectomy most frequent leak localization was the cystic duct stump (42\% of the cases), followed by common bile duct (35\%), hepatic common duct (14\%) and hepatic bed (7\%). Regarding conventional cholecystectomy, the most frequent localization was the cystic duct stump ( $66 \%)$, followed by common bile duct $(22 \%)$, and hepatic bed $(11 \%)$. Interestingly there were no cases of hepatic common duct leaks in conventional cholecystectomy cases. In all cases secondary to hepatectomy (three) and hepatic trauma (five) the localization of the leak was the common hepatic duct.

Of the 31 patients, $23(74 \%)$ did not have biliary dilatation and $8(26 \%)$ had. Only two of the 31 cases needed to have surgery after the ERCP to suture the leak $(6.5 \%)$ and the procedure was not considered therapeutic. Both were from common hepatic leaks. In the first case the guidewire progressed only to the site of leak and 
stent placement could not be placed. In the other case, although sphincterotomy and stenting were successfully realized, it was not enough to treat the leak. In both cases further surgery was necessary.

Considering adverse events related to the procedure, from the 31 cases, $1(3.2 \%)$ had mild pancreatitis, with good resolution. There was one case in which ERCP was not therapeutic and evolved with abdominal sepsis after the procedure, with good resolution after antibiotics and surgery. There were no cases of perforation, bleeding, or death related to the procedure.

Regarding the treatment used, $71 \%$ of the patients were treated with sphincterotomy plus stent placement, and 29\% with papillotomy alone (or fistulotomy when necessary). Data including volume of the abdominal surgical drainage before and after each procedure (measured $48 \mathrm{~h}$ after ERCP) are shown at TABLE 2. Comparative analysis between the volume of drainage before and after each technique can be seen in FIGURES 1 and 2, respectively. We also evaluated the days until the drain was removed or cessation of drainage occurred, after ERCP as seen at TABLE 3. There was significant difference between the volume drained before and after both procedures $(P<0.05)$. However, when compared sphincterotomy alone and sphincterotomy plus stent placement there was no statistical difference between them $(P>0.05)$. In sphincterotomy alone group the average drained volume before ERCP was $211 \pm 102$ and after $35 \pm 41(P=0.018)$ while in stent group was $356 \pm 217$ and $98.67 \pm 106.21(P=0.001)$ respectively. FIGURE 3 shows comparative analysis regarding days needed for cessation of drainage or removal of the abdominal surgical drain after each treatment. Analyzing both techniques as the days needed to remove the ab-

TABLE 2. Comparative analysis between the volume of the surgical abdominal drain before and after each treatment.

\begin{tabular}{lccc}
\hline Drained volume & $\begin{array}{c}\text { Stent } \\
\text { placement }\end{array}$ & $\begin{array}{c}\text { Sphincterotomy } \\
\text { alone }\end{array}$ & $\boldsymbol{P}_{\text {-value }}$ \\
\hline $\begin{array}{l}\text { Drained volume } \\
\text { before ERCP }\end{array}$ & $356.33 \pm 217.78$ & $211.43 \pm 102.34$ & 0.078 \\
$\begin{array}{l}\text { Drained volume } \\
\text { ffter ERCP }\end{array}$ & $98.67 \pm 106.21$ & $35.71 \pm 41.07$ & 0.298 \\
$P$-value & $0.001 * *$ & $0.018 * *$ & \\
\hline
\end{tabular}

ERCP: endoscopic retrograde cholangiopancreatography. A: Wilcoxon test (95\% confidence). B: Mann-Whitney U test (95\% confidence). **Statistical significance (95\% confidence).

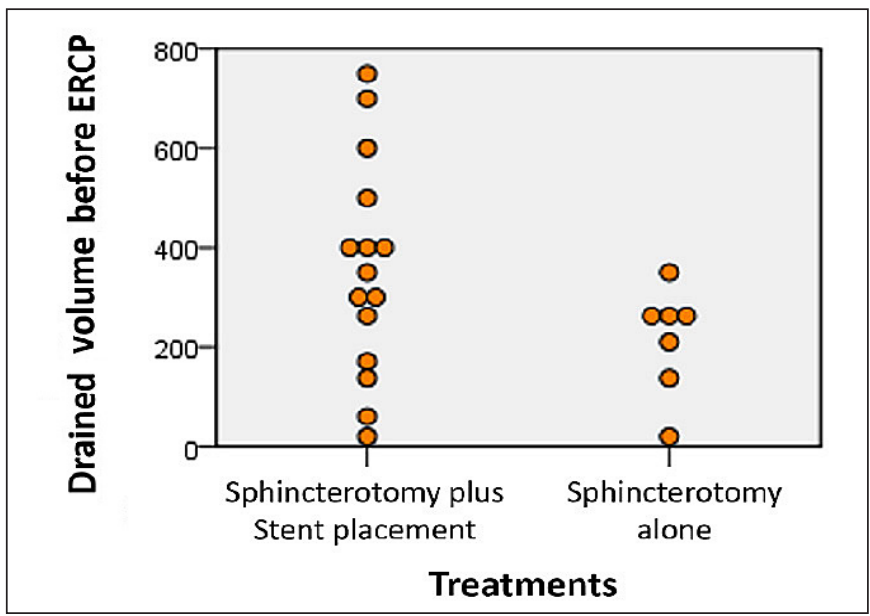

FIGURE 1.Volume of surgical drain before endoscopic retrograde cholangiopancreatography (ERCP) (in milliliters).

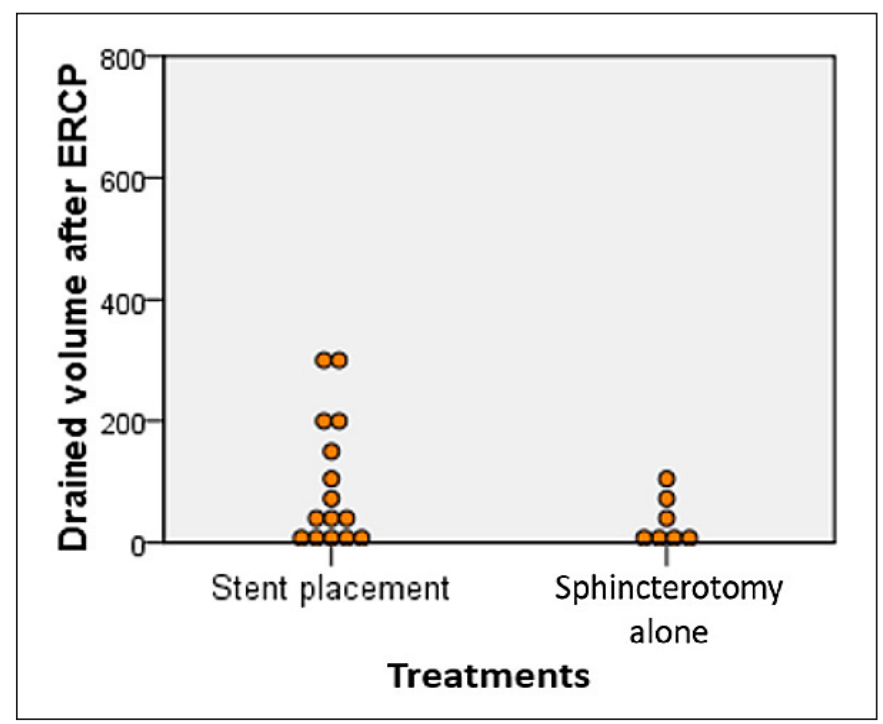

FIGURE 2. Volume of surgical drain after endoscopic retrograde cholangiopancreatography (ERCP) (in milliliters).

TABLE 3. Analysis of variation regarding days needed for cessation of surgical drainage after each treatment.

\begin{tabular}{lccc}
\hline $\begin{array}{l}\text { Days needed for } \\
\text { cessation of drainage }\end{array}$ & Average & $\begin{array}{l}\text { Standard } \\
\text { deviation }\end{array}$ & $\boldsymbol{P}$-value* \\
\hline Stent placement & 8 & 6 & 0.764 \\
Sphincterotomy alone & 11 & 16 & \\
\hline
\end{tabular}

* Mann-Whitney U test (95\% confidence).

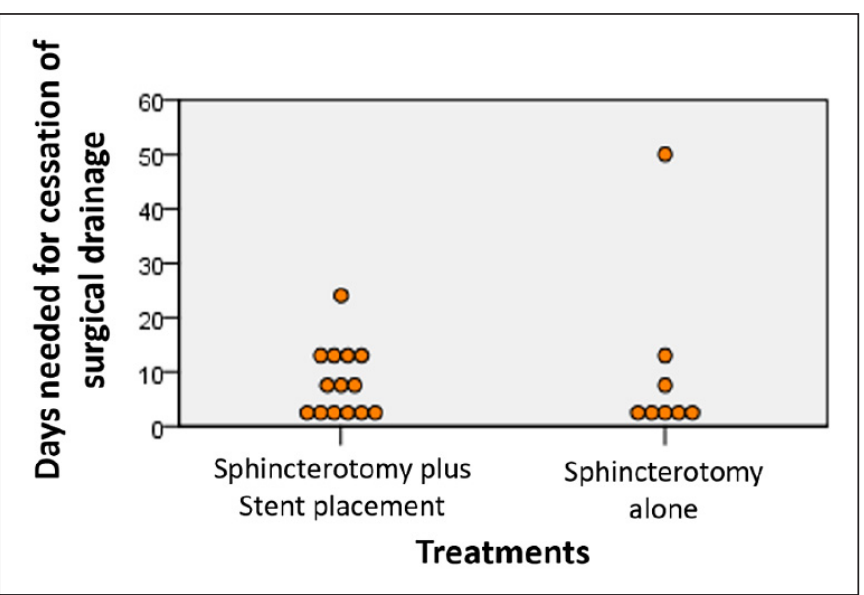

FIGURE 3. Days needed for cessation of surgical drainage.

dominal surgical drain or cessation of drainage after ERCP, there was no statistical difference $(P>0.05)$. In stent group the average were 8 days, while in sphincterotomy alone group 11 days were needed until the drain could be removed.

\section{DISCUSSION}

Bile leaks are a concerning complication after hepatobiliary surgery. Less commonly, abdominal trauma with hepatic damage can also be the etiology of bile leaks. Cholecystectomy is one of 
the most common types of abdominal surgery and bile leaks post cholecystectomy can result in increased morbidity, mortality, hospital expenditures and a decreased quality of a patient's life ${ }^{(14)}$. Other frequent causes of bile leaks include biliopancreatic surgery, liver transplants, hepatectomies and hepatic trauma ${ }^{(12)}$. ERCP is the standard diagnostic and treatment modality for bile leaks ${ }^{(15)}$. They are associated with less morbidity than surgery and are a good alternative to radiological interventions. The mechanism of resolution of the leakage is lowering the transpapillary pressure, with a sphincterotomy, biliary stent placement or combination of both ${ }^{(16)}$. ERCP will lead to a decrease in the flow resistance of bile duct facilitating leak sealing. Although there is no need to seal the leak orifice with the stent, stent placement is based on the preference of the endoscopist and there is no consensus on whether this is beneficial.

The grade of the bile leak is an important concern when considering ERCP techniques as the treatment. Sandha et al. ${ }^{(13)}$ reviewed 207 patients with bile leak diagnostic that undergone open or laparoscopic cholecystectomy. The leaks were classified as: low grade (leak identified only after intrahepatic opacification) and high grade (leak observed before intrahepatic opacification). In the same study was showed that sphincterotomy alone is a safe and effective treatment for low grade leaks and regarding high grade leaks the recommendation remains biliary stenting ${ }^{(13,17)}$. However, this is not a consensus. Dolay et al. ${ }^{(18)}$ concluded that biliary stenting seems to be a more effective method than sphincterotomy in post cholecystectomy bile leaks without CBD dilatation ${ }^{(12,18)}$. Kaffes et al. analysis indicates that stent insertion, may be superior to sphincterotomy alone in patients with post cholecystectomy bile leak, independent of the size of the stent ${ }^{(19)}$ FIGURE 4 shows an ERCP performed after a laparoscopic cholecystectomy with a bile leak from common bile duct. After 8 weeks of biliary stenting, the procedure was repeated with total seal of the leak, as shown in FIGURE 5 with no extravasation of the contrast.

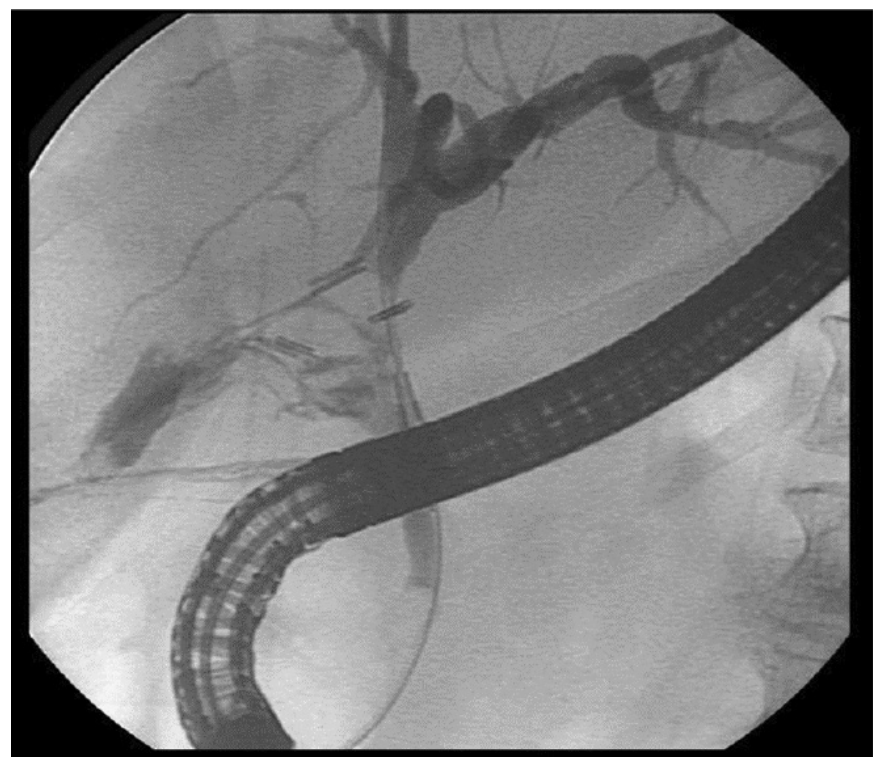

FIGURE 4. Post Laparoscopic Cholecystectomy leak: it's possible to observe extravasation of contrast from common bile duct (courtesy of Dr Everson L.A. Artifon).

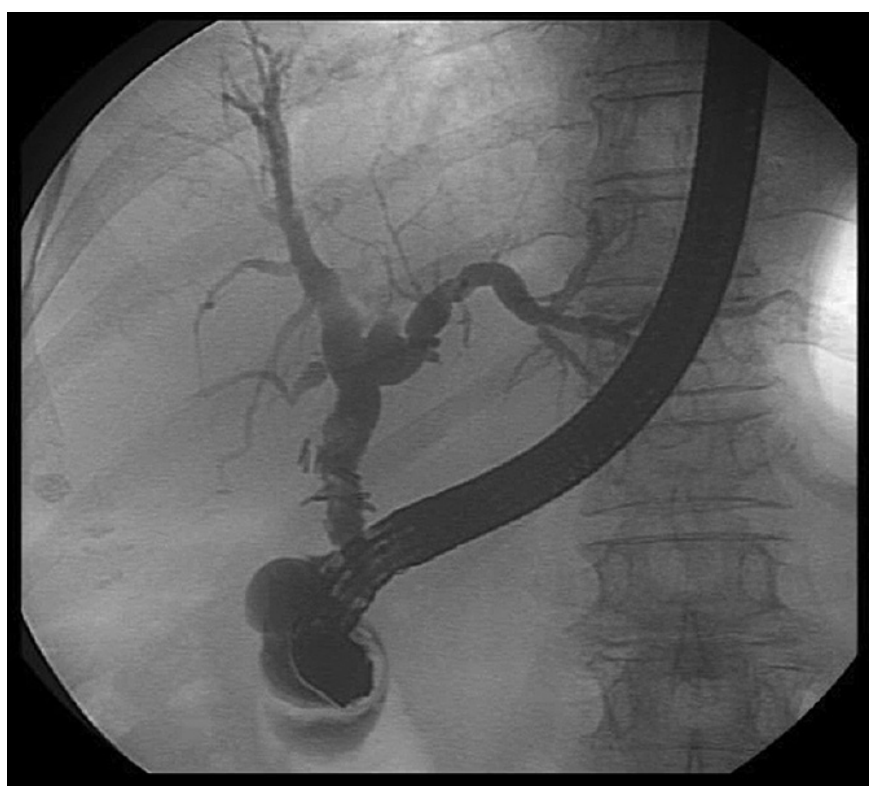

FIGURE 5. Same case from figure 7: Cholangiogram after 8 weeks at stent removal(courtesy of Dr Everson L.A. Artifon).

The liver and spleen are the most common organs injured after abdominal trauma ${ }^{(20)} .85-89 \%$ of hemodynamically stable patients with liver injury from blunt abdominal trauma can be managed safely without surgery ${ }^{(5,6)}$. The first concern in patients with hepatic trauma is hemorrhage, and stabilizing patients hemodynamically is critical. If this is not possible, surgery is most likely indicated. Conservative treatment includes arteriography and selective embolization, computed tomography guided drainage of collections and ERCP with sphincterotomy and biliary stent placement ${ }^{(5,20)}$. Recent studies have shown that ERCP is an effective treatment for bile leaks secondary to traumatic liver injuries, with more than $80 \%$ success rate ${ }^{(21)}$. In all five cases of bile leak secondary to hepatic trauma ERCP was successfully used in treatment with a decrease in abdominal surgical drainage volume after the procedure, and cessation of the drainage in 1-7 (minimum 1 and maximum 7) days, concluding that in our casuistic ERCP was effective and safe to treat bile leaks after hepatic complex trauma.

Despite the technical advances in hepatic surgery, bile leaks remain a feared complication of these surgeries. In Martin et al. study nearly $8 \%$ of all liver resections developed bile leak after hepatectomy and when bile duct reconstruction was present, this rate importantly increased to $29 \%{ }^{(11)}$. ERCP success rates after liver resections are lower than in post cholecystectomy (75\% versus 70 to $100 \%$ respectively), and other techniques as Rendezvous may be necessary. In our study we analyzed three hepatectomies secondary to due to neoplasia, and all the procedures were concluded with sphincterotomy. Two of the three cases were successfully treated with ERCP and resolution of the leak. In the third case, despite ERCP with sphincterotomy and stent placement was concluded, the patient had a major bile leak from common hepatic duct, and the ERCP was not capable to solve the leak, with necessity of further surgery.

When comparing the overall success between sphincterotomy and sphincterotomy plus stent placement there was no statistical difference. We compared the volume of the abdominal drain before and after ERCP, with a significant amount of drainage after both 
procedures, with no difference in drainage between them. Similarly, there was not a significant difference in the number of days needed to remove the abdominal drain between the two techniques.

Self-expandable metal stents (SEMS) are another option used in the treatment of bile leaks. Because of its larger diameter, they may more effectively divert bile away from the site of the leak ${ }^{(3)}$. In Wang et al. study the use of SEMS was analyzed in the treatment of complex bile leaks after cholecystectomy or liver transplantation, showed efficacy at resolving bile leaks, however associated with ulcerations, choledocholithiasis and stenosis ${ }^{(22)}$.

Our study, as a retrospective single center analysis, has its limitations, there may be a selection bias on witch cases the stent was placed, limiting the comparisons the can be made on this study between the two approaches on the treatment of biliary leaks. The chosen technique was decided by the senior endoscopist during the procedure according to operator experience. Stent placement without a sphincterotomy should be considered, principally in young patients, due to the risk of late development of bile duct cancer after sphincterotomy. Hakamada et al. showed in his study a 7.4\% prevalence of cholangiocarcinoma among 108 cases of sphincterotomy at intervals 1 to 20 years and considered the chronic cholangitis as the probably causative factor of this development, suggesting that these patients should be closely monitored ${ }^{(23)}$. Another reason to consider stenting without sphincterotomy in young patients, is because this is considered a group of risk for post-ERCP pancreatitis (PEP) ${ }^{(24)}$. FIGURE 6 shows an example of biliary stenting without sphincterotomy, with success and good drainage of bile.

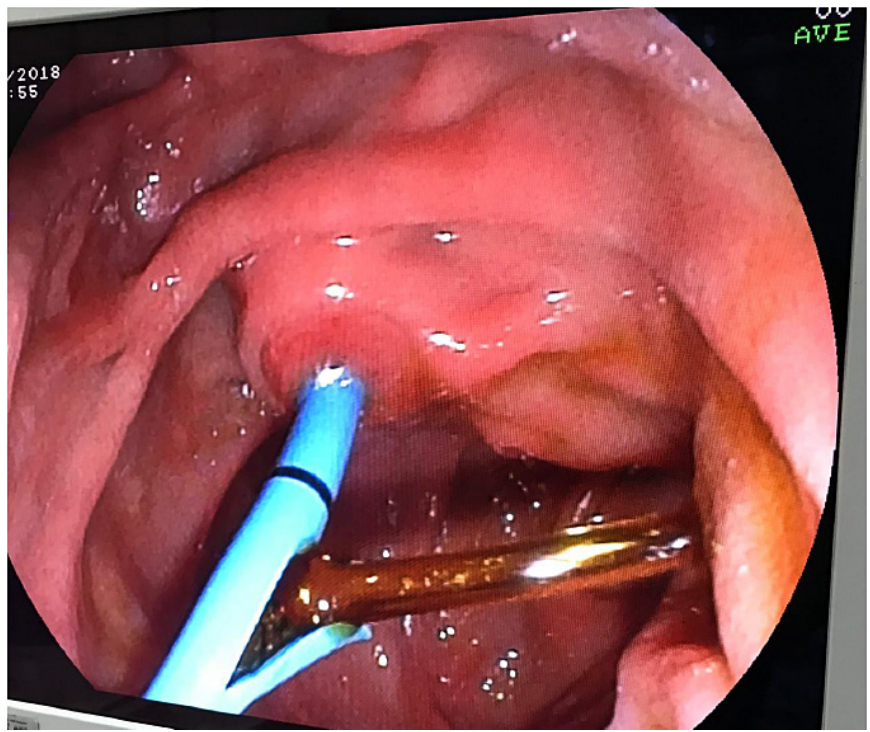

FIGURE 6. Suggestion of treatment for bile leaks in young patients: Stenting without sphincterotomy may prevent late biliary cancer development.
Despite the limitations presented, our study analyzed the different causes of bile leaks, comparing their treatments and results, different from the most other studies that analyzed just one etiology of bile leaks. A prospective study would take much longer to perform and will likely need to include multiple centers. We considered the success of ERCPs when it could be used to resolve the leak, without any further surgery or intervention. Among the 31 ERCPs performed, two were not successful procedures. In the first unsuccessful procedure, ERCP was not technically possible because it was a major bile leak, and in the second unsuccessful procedure, despite the successful ERCP the patient needed further interventions to resolve the leak. The two unsuccessful cases were common hepatic duct leaks, reinforcing studies that show that the location of the leak predicts the success of the $\operatorname{ERCP}^{(3,25)}$. Tewani et al. suggests that ERCP is 3.3 times more likely to be successful in bile leaks in the cystic duct stump or duct of Luschka, than in other locations ${ }^{(3)}$.

\section{CONCLUSION}

In conclusion, we suggest the treatment of bile leaks with ERCP as the standard of care, independent of the etiology of the bile leak. Leaks from the cystic duct stump are more likely to resolve with ERCP. We conclude that both sphincterotomy and stent placement are highly effective in the resolution of the leaks with no significant difference in outcomes. We also conclude that leaks of the common hepatic duct are less likely to achieve success with endoscopic procedures. In summary, ERCP remains the first line treatment in the diagnosis and treatment of bile leaks, and both sphincterotomy alone and biliary sphincterotomy with biliary stent placement are safe and effective treatments.

\section{ACKNOWLEDGEMENTS}

Thanks to Dr Helio T Tanaka for his help and advices. Thanks to Dr Everson L A Artifon for the courtesy of the photos used in this research. Thanks to Dr Diogo T H de Moura for his advices.

\section{Authors' contribution}

Flumignan VK: conceptualization, methodology, project administration, writing-original draft, and writing-review and editing. Sachdev AH: writing-review and editing. Nunes JPS, Silva PF, Pires LHB, Andreoti MM: data curation.

\section{Orcid}

Flumignan VK: 0000-0003-3591-1237.

Sachdev AH: 0000-0002-4576-8334.

Nunes JPS: 0000-0001-5425-5728.

Silva PF: 0000-0001-8067-7879.

Pires LHB: 0000-0001-5441-5920.

Andreoti MM: 0000-0001-9120-0603. 
Flumignan VK, Sachdev AH, Nunes JPS, Silva PF, Pires LHB, Andreoti MM. Esfincterotomia isolada versus esfincterotomia associada a passagem de prótese biliar no tratamento de fístulas biliares: 10 anos de experiência de um hospital quaternário. Arq Gastroenterol. 2021;58(1):71-6.

RESUMO - Contexto - Cirurgia hepatobiliar e trauma hepático são causas frequentes de fístulas biliares, e esta temida complicação pode ser manejada de forma segura através da colangiopancreatografia retrógrada endoscópica (CPRE). O procedimento consiste em esfincterotomia isolada, passagem de prótese biliar ou combinação das duas técnicas, porém a forma ideal permanece incerta. Objetivo - O objetivo desse estudo é comparar a realização de esfincterotomia isolada versus locação de prótese biliar no tratamento de fístulas pós-cirúrgicas e traumáticas. Métodos - Foram analisados de forma retrospectiva 31 CPREs com diagnóstico final de "fístula biliar". A informação colhida incluía dados demográficos dos pacientes, etiologia das fístulas e detalhes dos procedimentos. As técnicas de tratamentos foram divididas em dois grupos: esfincterotomia isolada vs esfincterotomia associada a locação de prótese biliar. Foram analisados os volumes dos drenos abdominais cirúrgicos antes e depois de cada procedimento e o número de dias necessários para que ocorresse cessação da drenagem pelo dreno abdominal cirúrgico após a CPRE. Resultados - Um total de 31 pacientes (18 homens e 3 mulheres; idade média de 51 anos) com fístulas biliares foram avaliados. Colecistectomia laparoscópica foi a etiologia da fístula em $14(45 \%)$ casos, seguida de colecistectomia convenvional em $9(29 \%)$ pacientes, trauma hepático em $5(16 \%)$ pacientes, e hepatectomia secundária a neoplasia em 3 (9,7\%) pacientes. As localizações mais frequentes das fístulas foram: coto do ducto císticos com 12 (38,6\%) casos, seguido de ducto hepático comum em $10(32 \%)$ casos, ducto colédoco em 7 (22\%) cases e leito hepático em $2(6,5 \%)$ casos. $71 \%$ dos pacientes foram tratados com esfincterotomia associada a passagem de prótese biliar e $29 \%$ com esfincterotomia isolada. Houve diferença estatística em relação ao volume drenado antes e depois de ambos os procedimentos $(P<0,05)$. Entretanto, quando comparada esfincterotomia isolada e esfincterotomia associada a passagem de prótese biliar, em relação ao volume drenado e ao número de dias necessários para cessação da drenagem, não houve diferença estatística em ambos os casos $(P>0,005)$. Conclusão - A CPRE permanece como tratamento de primeira linha no tratamento de fístulas biliares, sem diferença entra a esfincterotomia isolada versus esfincterotomia associada a passagem de prótese biliar.

DESCRITORES - Fístula biliar. Esfincterotomia. Stents. Colangiopancreatografia retrógrada endoscópica. Colecistectomia.

\section{REFERENCES}

1. Adler DG, Papachristou GI, Taylor LJ, McVay T, Birch M, Francis G, et al Clinical outcomes in patients with bile leaks treated via ERCP with regard to the timing of ERCP: a large multicenter study. Gastrointest Endosc. 2017;85:766-72. doi:10.1016/j.gie.2016.08.018

2. Vlaemynck K, Lahousse L, Vanlander A, Piessevaux H, Hindryckx P. Endoscopic management of biliary leaks: a systematic review with meta-analysis. Endoscopy. 2019;51:1074-81. doi:10.1055/a-0835-5940

3. Tewani SK, Turner BG, Chuttani R, Pleskow DK, Sawhney MS. Location of bile leak predicts the success of ERCP performed for postoperative bile leaks. Gastrointest Endosc. 2013;77:601-8. doi:10.1016/j.gie.2012.11.026

4. Abbas A, Sethi S, Brady P, Taunk P. Endoscopic management of postcholecystectomy biliary leak: When and how? A nationwide study. Gastrointest Endosc. 2019;90:233-241.e1. doi:10.1016/j.gie.2019.03.1173

5. Lubezky N, Konikoff FM, Rosin D, Carmon E, Kluger Y, Ben-Haim M. Endoscopic sphincterotomy and temporary internal stenting for bile leaks following complex hepatic trauma. Br J Surg. 2006;93:78-81. doi:10.1002/bjs.5195

6. Croce MA, Fabian TC, Menke PG, et al. Nonoperative management of blunt hepatic trauma is the treatment of choice for hemodynamically stable patients Results of a prospective trial. Ann Surg. 1995;221:744-55. doi:10.1097/00000658 199506000-00013

7. Sharma H, Bird G. Endoscopic management of postcholecystectomy biliary leaks. Frontline Gastroenterol. 2011;2:230-3. doi:10.1136/flgastro-2011-100031

8. Cohen JT, Charpentier KP, Beard RE. An Update on Iatrogenic Biliary Injuries: Identification, Classification, and Management. Surg Clin North Am. 2019;99:283-99. doi:10.1016/j.suc.2018.11.006

9. Rustagi T, Aslanian HR. Endoscopic management of biliary leaks after laparoscopic cholecystectomy. J Clin Gastroenterol. 2014;48:674-8. doi:10.1097/ MCG.0000000000000044

10. Bergman JJ, van den Brink GR, Rauws EA, et al. Treatment of bile duct lesions after laparoscopic cholecystectomy. Gut. 1996;38:141-7. doi:10.1136/gut.38.1.141

11. Martin AN, Narayanan S, Turrentine FE, et al. Clinical Factors and Postoperative Impact of Bile Leak After Liver Resection. J Gastrointest Surg. 2018;22:661-7. doi:10.1007/s11605-017-3650-4.

12. Rainio M, Lindström O, Udd M, Haapamäki C, Nordin A, Kylänpää L. Endoscopic Therapy of Biliary Injury After Cholecystectomy. Dig Dis Sci. 2018;63:47480. doi: 10.1007/s10620-017-4768-7.

13. Sandha GS, Bourke MJ, Haber GB, Kortan PP. Endoscopic therapy for bile leak based on a new classification: results in 207 patients. Gastrointest Endosc. 2004;60:567-74. doi:10.1016/s0016-5107(04)01892-9
14. Pandit N, Yadav TN, Awale L, Deo KB, Dhakal Y, Adhikary S. Current Scenario of Postcholecystectomy Bile Leak and Bile Duct Injury at a Tertiary Care Referral Centre of Nepal. Minim Invasive Surg. 2020;2020:4382307. doi: $10.1155 / 2020 / 4382307$

15. Fasoulas K, Zavos C, Chatzimavroudis G, Trakateli C, Vasiliadis T, Ioannidis A, et al. Eleven-year experience on the endoscopic treatment of post-cholecystectomy bile leaks. Ann Gastroenterol. 2011;24:200-5.

16. Yun SU, Cheon YK, Shim CS, Lee TY, Yu HM, Chung HA, et al. The outcome of endoscopic management of bile leakage after hepatobiliary surgery. Korean J Intern Med. 2017;32:79-84. doi:10.3904/kjim.2015.165

17. Ghazanfar S, Qureshi S, Leghari A, Taj MA, Niaz SK, Quraishy MS. Endoscopic management of post operative bile duct injuries. J Pak Med Assoc. 2012;62:257-62.

18. Dolay K, Soylu A, Aygun E. The role of ERCP in the management of bile leakage: endoscopic sphincterotomy versus biliary stenting. J Laparoendosc Adv Surg Tech A. 2010;20:455-9. doi:10.1089/lap.2009.0308

19. Kaffes AJ, Hourigan L, De Luca N, Byth K, Williams SJ, Bourke MJ. Impact of endoscopic intervention in 100 patients with suspected postcholecystectomy bile leak. Gastrointest Endosc. 2005;61:269-75. doi:10.1016/s0016-5107(04) 02468-x

20. Brillantino A, Iacobellis F, Festa P, Mottola A, Acampora C, Corvino F, et al. Non-Operative Management of Blunt Liver Trauma: Safety, Efficacy and Complications of a Standardized Treatment Protocol. Bull Emerg Trauma. 2019;7:49-54. doi:10.29252/beat-070107

21. Khamaysi I, Suissa A, Yassin K, Gralnek IM. Traumatic bile leak in war-injured Syrians: five patients treated by ERCP. Endoscopy. 2015;47 (Suppl 1 UCTN):E426-E427. doi:10.1055/s-0034-1392656.

22. Wang AY, Ellen K, Berg CL, Schmitt TM, Kahaleh M. Fully covered self-expandable metallic stents in the management of complex biliary leaks: preliminary data - a case series. Endoscopy. 2009:41(9):781-786. doi:10.1055/s-0029-1215050

23. Hakamada K, Sasaki M, Endoh M, Itoh T, Morita T, Konn M. Late development of bile duct cancer after sphincteroplasty: a ten- to twenty-two-year follow-up study. Surgery. 1997;121:488-92. doi:10.1016/s0039-6060(97)90101-x

24. Rustagi T, Jamidar PA. Endoscopic retrograde cholangiopancreatography (ER$\mathrm{CP})$-related adverse events: post-ERCP pancreatitis. Gastrointest Endosc Clin N Am. 2015;25:107-21. doi:10.1016/j.giec.2014.09.006.

25. Yabe S, Kato H, Mizukawa S, Akimoto Y, Uchida D, Seki H, et al. Predictive factors for outcomes of patients undergoing endoscopic therapy for bile leak after hepatobiliary surgery. Dig Endosc. 2017;29:353-61. doi:10.1111/den.12798.

\section{(c) BY-NC}

